\title{
1. European governance and political entrepreneurship in times of economic crisis
}

\section{Daniel Silander}

One major challenge for the member states of the European Union (EU) over the last two decades has been the economic crisis that began in 2007-2008. The global economic crisis (Amadeo, 2016; Nier and Forte, 2016; Suter and Herkenrath, 2012) has been assessed by economists and politicians as the worst crisis since the Great Depression of the 1930s (Dullien et al., 2010: 1). The crisis began in the United States (US) in 2007 (Nier and Forte, 2016) with indebtedness among homeowners, overvalued house prices and optimistic estimates of house price increases. While the financial system was overexposed to real estate, the major decline in real estate prices led to a system crisis in the US banking sector. In September 2008, the American investment bank Lehman Brothers collapsed, leading to immediate and desperate political actions to bail out other financial institutions. Bear Stearns and Merrill Lynch were sold for a bargain and Goldman Sachs and Morgan Stanley transformed into commercial banks with tougher regulations. All four major financial companies received government economic support (The Economist, 17 October 2007; RealtyTrac, January 2008; The State of the Nation's Housing, 2008; Dullien et al., 2010). In January 2011, the Financial Crisis Inquiry Commission (FCIC), appointed by the US government to investigate all causes of the economic crisis, listed the following factors:

Widespread failures in financial regulation, including the federal reserve's failure to stem the tide of toxic mortgages; Dramatic breakdowns in corporate governance including too many financial firms acting recklessly and taking on too much risk; An explosive mix of excessive borrowing and risk by households and Wall Street that put the financial system on a collision course with crisis; Key policy makers ill prepared for the crisis, lacking a full 
understanding of the financial system they oversaw; and systematic breaches in accountability and ethics at all levels. (FCIC, 2011)

The global economic crisis also hit hard on the European economies. Despite EU and member state countermeasures to limit the economic recession, stock markets continued to drop, house markets destabilised, unemployment rates increased and economic growth halted significantly throughout Europe. In 2009, the overall EU gross domestic product (GDP) had fallen by 4 per cent, industrial production slowed to early 1990s levels, 23 million people (about 10 per cent of the active population) had become unemployed and average deficits were 7 per cent of GDP with several national debts of 80 per cent or more of GDP (European Commission, 2010; Dullien et al., 2010; Financial Times, 2016). The European Commission pointed out causes of the crisis similar to those stated by the FCIC:

The crisis was preceded by a long term period of rapid credit growth, low risk premiums, abundant availability of liquidity, strong leveraging, soaring asset prices and the development of bubbles in the real estate sector. Over-stretched leveraging positions rendered financial institutions extremely vulnerable to corrections in asset markets. As a result a turn-around in a relatively small corner of the financial system (the US subprime market) was sufficient to topple the whole structure. (European Commission, 2009: 1)

The European economic crisis had different impacts in the north and south of Europe, where the latter was hit the hardest. While many European states, such as Germany and Sweden, could handle the economic recession and limit its negative impact, other states, such as Greece, Portugal and Spain, among others, were challenged by economic bankruptcy and political turmoil. The economic recession was visualised in many ways: economic crisis in real estate, construction and service sectors (Spain, Greece); economic diversification (Italy, Sweden); social stress in homelessness, curtailing of welfare benefits, poverty and social marginalisation (Spain, France, Italy, Greece, UK) and in spatial crises in the development of ghost towns (Spain) and limited infrastructure development (Greece, France).

Although the euro was largely protected, the long-term effects of the crisis in declining growth, rising unemployment and social tension led to political instability, disintegration, nationalism, protectionism and mistrust towards governments and the EU. In numerous European elections - in the Netherlands, France, Italy and Germany, among many states - and in the European Parliament, Eurosceptic candidates gained greater popular support. The economic crisis embedded social and 
political tension in many European states with demonstrations, rioting and rising social movements (Turcu et al., 2015). In 2009, the European Commission declared the crisis as "without precedent in post-war economic history" (European Commission, 2009: 1) and called for actions "to be bold and ambitious" (European Commission, 2010: 2). In 2010, the European Commission visualised a new European political and economic start in the wake of the global crisis. The former president (2004-2014) of the Commission, José Manuel Barroso, called for coordinated, innovative and immediate European reactions to the crisis to build a better Europe. The EU responses had to be based on "real ownership by European leaders and institutions", "a coordinated European response" to "act together" and with "new tools and the new ambition" (see European Commission, 2010: 2-3).

In 2015, five years later, the EU Commission stated in its report on European Financial Stability and Integration how Europe was perhaps on a slow path towards economic recovery. The Commission foresaw a slow and winding road of economic progress based on monetary stimulus initiatives and structural and regulatory reforms. It stated that, "For the first time since 2007, the economies of all EU Member States are expected to grow in $2015 \ldots$.. Over the course of 2015, economic activity is expected to pick up moderately in the EU and in the euro area, before growing further in 2016" (European Commission, April 2015: 10). It also stated, however, that European economic recovery remained slow with the remaining economic crisis impacting Europe due to structural weaknesses, a slow path of investment recovery and limited impact of exports on economic growth, leaving private sector consumption as the main driving engine for European economic recovery (European Commission, April 2015: 10-11).

In early 2017, the EU Commission forecasted an economic turning point in Europe. The Commission expected an important economic recovery in 2016-2018 and declared that a decade of economic recession now seemed to be met by economic growth in all $28 \mathrm{EU}$ member states, although challenges and uncertainties remained. It was argued that this was at least partly due to the reforms the EU initiated and promoted to prevent, mitigate and resolve the economic crisis. First, crisis prevention involved identifying causes of the crisis and the necessary macroeconomic regulatory and supervisory mechanisms to be implemented. Second, crisis mitigation included limiting negative social and economic consequences of the recession, and third, crisis resolutions were adopted to halt the economic recession to the lowest possible economic and social costs for European citizens (European Commission, 2009: 1-2). The implemented policy reforms included governmental financial rescue 
policies to ensure a financial system of banks with liquidity: that is, raised deposit guarantees, low interest rents and state guaranteed liquidity facilities for institutions. The primary objectives were to develop financial policies that would restore the banking sector to being financially dynamic and to promote economic progress of productivity, but also to set up a functional regulative and supervisory framework for the financial market (European Commission, 2009: 2-5).

During a decade of European economic crisis, there have been numerous calls for European leadership with new, innovative and bold measures, that is, political entrepreneurship to counter the economic crisis. It was argued that European political entrepreneurship should be the cornerstone in a redeveloped, prosperous and highly modern European economy (Com, 2008, 394 final 2). Scholars in the social sciences and economics have also stated that European economic progress needs new political initiatives and collaboration within networks of different types of entrepreneurship and that it is within these networks that political entrepreneurship must thrive so as to set up institutional arrangements for a dynamic and prosperous Europe. In this study, to explore political entrepreneurship is to explore how European politicians, public servants, bureaucrats and institutions have acted to establish favourable conditions for economic growth and entrepreneurship in Europe. This book particularly explores if there exists, from a governance perspective, political entrepreneurship from the EU-member state authorities, politicians and public servants - to promote institutions favourable to growth and entrepreneurship in Europe in times of a long-lasting economic crisis. By political entrepreneurship, this study includes an actor and a structure perspective by focusing on politicians/ public servants/bureaucrats/institutions within the publicly funded sector that, with innovative approaches, encourage entrepreneurship/business and where the goals are growth and employment (Karlsson et al., 2016). By governance, we refer to the multilevel authorities that together constitute European political steering and where EU institutions, member state governments and local and regional authorities are core actors (Wallace et al., 2010; Hix, 1998; Rhodes, 1996). It is argued that contemporary EU multilevel governance provides new opportunities for political entrepreneurship to identify and develop policies on various levels of authority, from the local and subregional to state and European levels, and that a European economic crisis may provide a window of opportunity (Kingdon, 1984) for political entrepreneurial measures. 


\section{POLITICAL ENTREPRENEURSHIP AND EUROPEAN GOVERNANCE}

Political entrepreneurship has been frequently called for in European political discussions and especially so in times of social and economic challenges. The European debate has called for European leadership; innovative, bold and ambitious initiatives and new cohesive policies on the economic crisis. However, scholarly attention to political entrepreneurship and political entrepreneurs has been far more limited. Research on political entrepreneurship originally developed from an economics perspective on entrepreneurship and entrepreneurs as important aspects of a growing and dynamic economy (see Schumpeter, 1943). In traditional scholarly work in economics, entrepreneurs have been portrayed as economic driving engines and go-getters striving against the status quo for new ventures and windows of opportunity. In the 1990s, research on entrepreneurship and the entrepreneur slowly became multidisciplinary with new academic perspectives from behaviour science, sociology and anthropology, focusing on entrepreneurial characteristics, entrepreneurial behaviour, entrepreneurial networks and organisations (Grant, 1998). Such research perspectives led to a focus on entrepreneurs and entrepreneurship beyond the economic sector. Research shed light on entrepreneurship beyond the profit-seeking economic entrepreneur: social entrepreneurs were revealed as innovative leaders in cooperative associations, interest organisations, aid branches, infrastructure development, sustainable development, climate change, union issues, youth leisure, fair trade, animal protection and human rights (Westlund, 2010; Gawell et al., 2009; Borzaga et al., 2008; Brickerhoff, 2000). In more recent years, the multidisciplinary approach to entrepreneurship has also included political entrepreneurs (Scheingate, 2003). A political science perspective on entrepreneurship was introduced by Robert Dahl, who focused on resourceful and masterful leaders in the political sphere. He argued that a political entrepreneur was "the epitome of the self-made man" (1974: 25, 223-7, 282). While Homo civicus were active citizens trying to influence politicians to seek favourable policies, Homo politicus were citizens formally engaged in politics to shape politics. Based on this study, political entrepreneurship was about politically oriented individual capacity and ability to supply collective benefits to the many, but could also include seeking profit politically. The main objective for the political entrepreneur could be to provide goods/services to the many or a group of people to receive campaign contributions and/or political support 
(for elected politicians) and for public servants to receive political/ administrative support/status (Simmons et al., 2011).

Despite the growing bulk of studies on political entrepreneurship, scholarly work has been criticised on some assumptions. First, most studies have focused on the political entrepreneur from an actor-oriented perspective by exploring the political/public motives behind the political entrepreneurship. It has been assumed that there is an individual profitseeking objective for the political entrepreneur to act entrepreneurially in the political/public sector. Second, it has also been unclear what actually distinguishes political entrepreneurship from regular political/public activities in the public sector. Many studies have shown that politicians and bureaucrats may alter tax distribution, regulations and implementation procedures, but it is hard to explore how such day-to-day activities actually constitute political entrepreneurship in relation to ordinary political/public actions. The new institutionalism on entrepreneurship has, for example, explored how state authorities, both politicians and bureaucrats, may use coercively collected resources to promote economic activities (e.g. production, channelling tax money into different sectors, welfare distribution) that without state interference would not have happened (McCaffrey and Salerno, 2011: 556-8; see also Jones, 1978; Salerno, 2008; Holcombe, 2002; Schneider and Teske, 1992). Third, there are also questions about whether political entrepreneurship is about providing for change or providing for the status quo. Many studies have implied that political entrepreneurship could be about doing nothing-to seek no changes and to consolidate what is already established.

This study departs from the understanding that political entrepreneurship is about the public sector of public actors and structures (politicians, public servants, bureaucrats, institutions) that seek to create favourable conditions for other entrepreneurs (Silander and Silander, 2015; Karlsson et al., 2016; see also Schneider and Teske, 1992). It is about promoting favourable formal and informal institutions (North, 1990) for economic entrepreneurial activities and shaping and coordinating new procedures (McCaffrey and Salerno, 2011: 553) by making use of windows of opportunity (Kingdon, 1984). There is limited research on what political entrepreneurship should consist of to be successful. It must be stated that there is no single political entrepreneurial policy that is to be found as a universal solution to ongoing entrepreneurship, growth and employment. On the contrary, different geographical regions and economic sectors have different conditions. There is, therefore, no clear-cut policy to be implemented, but rather different policies according to the settings in which entrepreneurial activities are to be boosted. The existing research points out that different 
macroregions (e.g. Europe), nations, subregions and municipalities have different conditions that may be better or worse for economic growth. The role of the political entrepreneur is to interpret and understand the existing conditions and set out innovative measures to promote economic prosperity. It may be to act in new, innovative ways on education, infrastructure, health care, rule of law, bureaucracy or taxation, but the bottom line is to address such conditions with new, bold path-breaking reforms. Political entrepreneurship is about challenging traditional formal institutions in political steering, leadership, strategies, policies, rules, regulations, laws and budgets for entrepreneurial activities and/or to challenge traditional informal institutions in ideas, attitudes, values, perceptions, images and symbols that structure public day-to-day activities and culture around entrepreneurship (North, 1990; Hofstede, 1991; Morgan, 1986; Putnam, 1993; Casson, 1995; Aldrich, 1990; Aldrich and Fiol, 1994). Political entrepreneurship is about challenging existing institutions (Finnemore and Sikkink, 1998: 891) regarding how to promote entrepreneurship and growth. Political entrepreneurship takes place when traditional institutions are challenged and altered and when new institutions, formal and/or informal, are promoted to better serve the interests of entrepreneurial activities and economic growth (Silander, 2016).

Decades of research on European politics and integration have implicitly touched upon what this study explores as European political entrepreneurship in times of economic crisis. The large bulk of research on European studies and EU studies has explicitly and convincingly identified how European and EU politics are changed by new, innovative political ideas and how such progress must be understood from a governance perspective by identifying how contemporary politics is conducted on local, regional, national and European levels (Aberbach and Rockman, 1994; Aberbach et al., 1981; Mintrom and Norman, 2009). Scholarly research on European studies began in the 1950s. The functionalist/neo-functionalist perspective (see Haas, 1958) analysed societal non-state actors as driving forces of integration that impacted political actors within European states in how they conducted politics in a European setting. It was argued that European integration was a "process whereby political actors in several distinct national settings are persuaded to shift their loyalties, expectations, and political activities toward a new centre, whose institutions possess or demand jurisdiction over the pre-existing national states" (Haas, 1958: 16). European integration was the result of societal elites persuading political domestic elites to seek new ventures beyond territorial barriers to fulfil social and economic wants. Political and economic collaboration between elites within one 
sector was stated to spill over to others, providing for transnational and supranational integration.

Neo-functionalism was debated from an intergovernmentalism perspective (Moravcsik, 1998, 1993) where scholars argued in favour of a viable and powerful sovereign state with entrepreneurial political elites. It was argued that decades of European integration were a result of national governments' decisions to seek collaboration with other governments to solve common social, economic and political challenges. Based on national preferences, governments had for decades initiated negotiations with other European governments by acting politically entrepreneurially to deal with European policy issues and challenges. This led to widened cooperation among more and more member states in an increasing number of policy areas, but also deepened collaboration within such areas based on national interests. It was argued that European integration was a result of commercial interests within major European powers and that the transfer of sovereignty to EU institutions had been based on national strategies to preserve and promote domestic economic interests. ${ }^{1}$ As expressed by Moravcsik,

In a world in which governments are, broadly speaking, rational and instrumental, integration can be seen as a process in which they define a series of underlying objectives or preferences, bargain to substantive agreements concerning cooperation and finally select appropriate international institutions in which to embed them. (1998: 5)

In the 1990s, Europeanisation was conceptually introduced and debated (Radaelli, 2000: 2; Olsen, 2002: 921). Europeanisation referred to a transformative political change in how politics is organised in Europe, but also in political content (Quaglia et al., 2007; Olsen, 2002; Dyson and Goetz, 2002; Börzel, 1999). Europeanisation has developed into a theoretical perspective embedding a top-down and bottom-up approach to political entrepreneurship and European politics. First, scholars have argued that Europeanisation is a top-down transformation of European politics where Europeanisation embeds the political impact from the EU in member states with regional and local authorities (see also Ladrech, 1994; Börzel and Risse, 2000; Hix and Goetz, 2000). Europeanisation refers to decisions taken on a European level, within the EU, and how such decision-making promotes political change within member states (Hix and Goetz, 2000). Top-down Europeanisation includes formal and informal aspects of politics and political entrepreneurship. The formal

1 For ideas on new intergovernmentalism, see Bickerton et al. (2015). 
aspects refer to pressure from the EU level on member states to change formal institutions in laws, regulations and policymaking procedures, but also informal institutions in norms, values, political ideas, attitudes and standards of behaviour for how member states conduct politics as part of a European community (Radaelli, 2000).

Europeanisation of member states has come easier in some states compared to others. The closer domestic politics has been to the European "standard", the easier Europeanisation has been in domestic politics. Scholars have talked in terms of domestic fit or misfit to European policies, regulations, norms and values. The more formal and informal EU institutions fit domestic policies and regulations, the smoother the process of Europeanisation. However, a greater misfit includes European pressure on domestic politicians and authorities to adjust to European political expectations (Börzel and Risse, 2000; Olsen, 2002). The scholarly discussion on fit and misfit between EU and individual member states has resulted in analysis of variations of Europeanisation from one state to another. The level of harmonisation between EU and domestic policies, regulations, norms and values may of course vary from one policy area to another, providing a complex system of Europeanisation between the EU level of politics and individual member states. Europeanisation in one policy area may have a high impact on individual states, while in others the misfit may be greater with higher pressure from the EU level but also greater resistance from the domestic level (Cowles et al., 2001; Wallace, 2000).

Second, scholars have also argued against a top-down definition of Europeanisation by describing the two-way process where the EU influences domestic politics, but also vice versa, where politics and political entrepreneurship within member state politics influence politics on a European level and within the EU. This bottom-up approach to Europeanisation (see Börzel, 2002; Risse et al., 2001) stresses the importance of member states and their impact on European politics and on EU institutions (Börzel, 2002). Scholars of bottom-up Europeanisation stress that Europeanisation is a dual process of uploading and downloading and that European states are in no way passive entities, but rather are engaged in forming domestic and European politics in an interactive and interdependent pattern (Risse et al., 2001; Börzel, 2002: 193). Europeanisation as a dual process has gained increasing interest and impact in scholarly studies. Theories on intergovernmentalism have stated that European politics and the EU are a result of individual member states' seeking collaboration through political entrepreneurship in areas where they may be better off from a rational perspective. Europeanisation also comprises, therefore, bottom-up changes where 
member states individually and together are influencing and shaping EU institutions by uploading domestic agendas, policies, norms and values to a European level (Ladrech, 2010; Quaglia et al., 2007; Börzel and Panke, 2009; Börzel, 2002, 1999). ${ }^{2}$ As stated by Olsen,

Some scholars portray Europeanization as the institutionalization at the European level of a distinct system of governance with common institutions and the authority to make, implement and enforce European-wide binding policies ... Europeanization here includes both the strengthening of an organizational capacity for collective action and the development of common ideas, such as new norms and collective action and the development of common ideas, such as new forms and collective understandings regarding citizenship and membership ... A possible frame for understanding the dynamics and outcomes of European-level institutional development is purposeful choice. Within this frame, which is used by intergovernmentalists in particular, a group of actors have a choice between alternative forms of organization and governance ... They choose the one that, according to its inherent properties or expected effects, is assessed as being most valuable. Institutional developments, then, are seen as reflecting the will, power and understanding of identifiable actors. (2002: 929)

The scholarly literature on top-down and bottom-up Europeanisation and political entrepreneurship is strongly linked to the scholarly debate on governance (Héritier et al., 2001). Europeanisation has implied a transformation of European politics in terms of organisational structure and authoritative institutions, decision-making procedures and norms and values. It has been argued that European politics has come to be conducted on different levels of authority and in new networks of political relations with possibilities for political entrepreneurship from multiple formal actors within European governance. The most obvious political symbols of Europeanisation have been the development of the EU, the transfer of sovereignty to the EU level and the new myriad relations and networks of local, regional, national, transnational and European actors that are today engaged in European politics. Over time, the EU has widened and deepened and become a significant political power in European politics (Quaglia et al., 2007; Hix and Goetz, 2000). It has been most obvious in those policy areas where the EU has supreme authority, but the EU has, through political entrepreneurship, expanded its competence to new policy areas, which has resulted in direct

2 A third, final approach to Europeanisation has emphasised a mid-approach, a horizontal transfer of politics from one EU member state to another. Horizontal Europeanisation refers to how individual member states influence other member states through cooperation within or outside the EU. 
Europeanisation of member states. However, Europeanisation may also come as a consequence of spillover effects from one policy area to another. Therefore, although the member states formally have authority over a policy area, Europeanisation may influence member states and non-member states due to deepened cooperation in one area that leads to cooperation in others (Ladrech, 2010; Wallace, 2000). This has led to a European institutional fuzziness with changed patterns of authority in the multilevel EU governance in national, transnational and EU institutions. Political entrepreneurship, new policy ideas, policy formulation and policymaking and implementation are taking place in contemporary Europe on different levels. Although EU member states and EU institutions are core actors in European politics, there are also transnational, regional and local actors involved in shaping policies in the European system of governance (Marks and Hooghe, 2001). These multilevel authorities are also involved in networks across territories (Castells, 1996; Keohane and Nye, 1977), engaging companies, industries, unions and civil society organisations within education, economics, culture, the environment and social rights with their activities of lobbying and campaigning to impact authorities domestically and on a European level through double-edged diplomacy. As stated by Risse et al.:

We define Europeanization as the emergence and development at the European level of distinct structures of governance, that is, of political, legal, and social institutions associated with political problem-solving that formalize interactions among the actors, and of policy networks specializing in the creation of authoritative rules. (2001: 3)

It was already argued in the globalisation literature of the 1990s that "political communities are in the process of being transformed" (Held, 2000: 17). In Europe, Europeanisation embeds changes of external European boundaries where Europe as geographical and political space becomes one; Europeanisation embeds the development of European institutions, formal and informal ones, that become a new political structure of coordination, coherence and capacities; Europeanisation implies how such European institutions penetrate national and subnational political space and together construct a multilevel system of European authorities; Europeanisation finally includes how Europe as a political entity and space relates to and promotes European political structures, norms and values regionally and globally beyond European frontiers (Olsen, 2002: 923-4). 
The deepening and widening of the EU over the last decades (Avery and Cameron, 1999) has led to a bulk of studies on European transformations and EU governance. The deepening process has included the transfer of sovereignty from member states to the EU in an expanding number of policy areas. The widening process has referred to the increasing number of member states. The EU has become an organisational hybrid of international and supranational cooperation. While most politics is formally organised in terms of state politics, discussions and decisions have increasingly been transferred to the EU level of politics. While some studies on European governance have stressed the EU as sui generis, a unique political phenomenon that needs its own theoretical and empirical studies, EU governance should rather be understood as a regional political entity with advanced levels of regional deepening and widening. EU governance is on one hand about politics and political entrepreneurship in Brussels, Luxembourg and Strasbourg and on the other hand national, regional and local authorities. European governance should, therefore, be understood as a multilevel system of local, regional, state and European authorities engaged in a complex system of politics and political entrepreneurship with top-down and bottom-up processes of Europeanisation (Wallace et al., 2010).

Today, the EU and its member states have a division of competences. This division is referred to in the Treaties and more specifically the Treaty of Lisbon (Lisbon Treaty, 2009). The fundamental division of authority is that the EU has only the competences set out in the Lisbon Treaty. Competences not referred to in the Treaty remain at the state level. The Treaty of Lisbon sets out the division of competences between the EU and its member states in three main categories: exclusive competences, shared competences and supporting competences. First, exclusive competences are stated in Article 3 of the Treaty of Lisbon on the Functioning of the European Union; TFEU) and identify areas where the EU as political entity is the main authority to legislate and adopt binding acts. In these areas, individual member states have transferred sovereignty to the collective will of the EU and are only able to implement policies when they are empowered by the EU. It is the EU, through the Commission, that initiates and implements laws and regulations based on the mandate set out in the Treaty. It is the role of the Council, the Parliament and the European Court to assess the rights of the union in relation to what the Treaty says. The EU possesses exclusive competence in the following areas:

- customs union; - the establishing of competition rules necessary for the functioning of the internal market;-monetary policy for euro area 
countries; - conservation of marine biological resources under the common fisheries policy;- - common commercial policy;- - conclusion of international agreements under certain conditions. (EUR-Lex, 2017: Division of competences within the EU)

Second, shared competences are set out in Article 4 of the Treaty of Lisbon and refer to where the EU and member states are mutually able to legislate and adopt legally binding acts. In these areas individual member states are sovereign to decide and legislate as long as the EU has not exercised authority or expressed intention to exercise authority. If an individual member state already has laws and regulations, the EU is not authorised to decide on new laws and regulations that could harm or jeopardise national regulations. Shared competence between the EU and member states is exercised in the following areas:

—internal market; - social policy, but only for aspects specifically defined in the Treaty;-economic, social and territorial cohesion (regional policy);agriculture and fisheries (except conservation of marine biological resources); environment;-consumer protection;- transport;- trans-European networks; - energy;-area of freedom, security and justice;-shared safety concerns in public health matters, limited to the aspects defined in the TFEU;-research, technological development, space;-development cooperation and humanitarian aid. (EUR-Lex, 2017: Division of competences within the EU)

Third and finally, supporting competences are listed in Article 6 of the Treaty of Lisbon that state the main authority is the individual member states and the EU may only support, coordinate or complement actions taken by states. The EU has no authority to call for harmonisation of state policies, laws and regulation, and can only have an assisting role in the implementation of decisions taken by states. Supporting competences concern the following:

—protection and improvement of human health;- -industry;-culture;tourism;--education, vocational training, youth and sport;-civil protection; —administrative cooperation. (EUR-Lex, 2017: Division of competences within the EU)

Traditional policymaking patterns in the EU have been complemented by the use of "soft" governance tools such as benchmarkingrecommendations on best practices and guidelines through the Open Method of Co-ordination process (OMC). The OMC was launched as part of the package from the Lisbon meeting in 2000 together with the European Employment Strategy as a way for the EU to act in areas where national situations differ substantially or where only limited competences 
exist on the EU level. OMC can be seen as a compromise to retain member state responsibility in an area while at the same time providing the EU with a coordinating and policy-shaping role (Warleigh-Lack and Drachenberg, 2013: 207). New modes of governance, including benchmarking and exchange of best practices, allow member states to coordinate policies at the same time as being executives because the member states are responsible for their compliance with the measures they have agreed on at the EU level. The OMC represents a voluntary and intergovernmental mode of cooperation.

In the OMC process, the Commission plays an important monitoring and agenda-setting role. The Council of Ministers is also central as it sets the policy goals and guidelines by unanimity. Member states submit annual reports on their progress and these reports are commented on and evaluated by the Commission. There is not one uniform OMC process; instead, it works differently depending on area. There are, however, a few common steps in the process. Step one is fixing the guidelines for the union combined with a timetable (what is to be completed in the short, medium and long term). Step two is to establish quantitative and qualitative indicators and benchmarks. Step three consists of translating the European guidelines into national and regional policies by setting specific targets and adopting measures for reaching such targets. Step four involves periodic monitoring and evaluations organised as mutual learning processes (see EUR-Lex, OMC, 2017).

The EU competences, in exclusive competences, shared competences and supporting competences, are all based on two fundamental principles of the EU as set out in Article 5 of the Treaty. The first principle is proportionality and refers to how all EU actions should be proportional to the objective to be met; that is, EU actions should not be more than necessary. The second principle is about subsidiarity and how the EU, on issues of non-exclusive competence, should refer decision-making to appropriate levels of authority. The EU is not to act upon issues in areas of non-EU competence, and could only intervene if EU member states are for some reason unable to fulfil the target goals and when such goals can be fulfilled on an EU level. It is important to acknowledge that, where the Treaty does not say anything about authority over policy areas, it is the individual state that has full sovereignty. Policy areas that are not explicitly regulated in the Treaty are formally for member states only to decide. For such policy areas to be included in EU competences requires approval by all member states and thereby a new ratification of a Treaty. It is only Article 352 that provides flexibility on these issues by referring decision-making power to the EU in non-EU policy areas if a measure is required to meet the overall objective of the policy area as set out in the 
Treaty. It does, however, require full approval from all member states in the Council of Ministers and approval from the European Parliament. The different kinds of competences leave the EU as a political hybrid of authorities where EU institutions represent union interests (Commission), member states' interests (Council of Ministers) and citizens' interests (Parliament) (see Lisbon Treaty). It should, however, also be stated that the three categories of competences only portray the official way politics is handled. In the daily life of politics these competences are challenged by practical hindrances and possibilities. Although the EU has exclusive competence in certain areas, it consists of member states in the Council of Ministers and national politicians in the Parliament who influence and decide on political issues that are thereafter to be implemented by national politicians and public servants at home. It should also be stated that in those areas where member states have full authority, often the decisions made and the laws implemented are influenced by the EU system, as national and European politics is interwoven in a network of official and unofficial ties.

\section{EUROPE 2020 AND THE STRUCTURE OF THIS STUDY}

In the famous and strategically important European Commission Communication of 2010, Europe 2020-A strategy for smart, sustainable and inclusive growth, the Commission called for European political entrepreneurship throughout the governance system of European authorities to act as a countermeasure to the existing economic crisis. The Commission argued that fundamental efforts beyond day-to-day activities had to be implemented by multiple formal actors: "The crisis is a wake-up call, the moment where we recognise that 'business as usual' would consign us to a gradual decline, to the second rank of the new global order. This is Europe's moment of truth. It is the time to be bold and ambitious" (European Commission, 2010: preface).

Europe 2020 embedded numerous initiatives with a focus on more jobs, research and innovation, climate change policies and energy, education and poverty reduction. Major and immediate reforms in these areas were portrayed by the Commission as urgent, necessary transformations to serve as countermeasures to the devastating economic and social impact the crisis had had on Europe. In the Communication, three main innovative objectives were identified in smart, sustainable and inclusive growth. It referred to smart growth in promoting an economy based on knowledge and innovation, sustainable growth based on resource efficiency and a greener economy and inclusive growth providing for social 
integration (European Commission, 2010: 5). To meet these goals, the Commission developed seven flagship initiatives and guidelines for how such flagships had to be launched and implemented through a shared European partnership from a multilevel governance perspective, including political, economic and social actors from local to European levels:

The European Council will have full ownership and be the focal point of the new strategy. The Commission will monitor progress towards the targets, facilitate policy exchange and make the necessary proposals to steer action and advance the EU flagship initiatives. The European Parliament will be a driving force to mobilise citizens and act as co-legislator on key initiatives. This partnership approach should extend to EU committees, to national parliaments and national, local and regional authorities, to social partners and to stakeholders and civil society so that everyone is involved in delivering on the vision. (European Commission, 2010: 6)

Europe 2020 proposed that the European Council would steer the project and consolidate the integration of policies and initiatives between the EU and member states through political guidance and direction. The Council of Ministers would implement flagship initiatives and discuss good practices. The Commission would annually monitor the progress made on each goal towards a smart, green and inclusive economy, assess member states' reports and provide policy recommendations. The European Parliament would engage citizens and civil society organisations and finally national, regional and local authorities individually and through the Committee of Regions to implement Europe 2020 by developing necessary and appropriate reforms in collaboration with citizens, civil society organisations and local businesses and entrepreneurs. European governance had to overcome different business structures, low levels of investment in research and enterprise, limited use of communication technologies and reluctance to see opportunities and innovations through shared new, bold commitments (European Commission, 2010: 28-30). Agenda 2020 should be perceived as an overall framework for European governance on the European economic crisis of 2007-2008 and onwards. The Agenda stressed the importance of both multilevel governance and political entrepreneurship in the economic crisis to see a future European economy of growth, entrepreneurship, employment and social integration. This chapter has addressed the notions of European governance and European political entrepreneurship in times of European economic crisis. It has been argued that Europeanisation is a transformative change of Europe and includes top-down and bottom-up dimensions. These dimensions of Europeanisation have influenced the organisation and content of European politics. The scholarly studies on governance have 
stressed how contemporary Europe is politically organised in a multilevel system. The many political authorities on different political levels are essential ingredients in what European governance looks like today. In a time of economic stress, the EU Commission and European governments have called for new, innovative political initiatives within the system of multilevel European governance to set out a new European path towards economic growth and prosperity.

Based on the above introduction, this study on European governance and political entrepreneurship in times of economic crisis is structured into four themes and a final concluding part. First, the theme of Framework of Study, including Chapters 1, 2 and 3, introduces a theoretical and conceptual discussion on political entrepreneurship. It is argued that, in times of economic stress, political entrepreneurship is essential to find new ways of promoting growth, employment and welfare. This combines an actor-structure approach by discussing political entrepreneurs as the actors that are creative and innovative and develop, consolidate and coordinate networks. Second, the theme on European Institutions on Entrepreneurship and Regional Growth, covered in Chapters 4 to 6, explores the three main bodies of the EU-the Commission, the Council of Ministers and the European Parliament-and their visions, programmes, strategies and debates on how to push for entrepreneurial development and growth in Europe. There are multiple models and theories on how policies could be developed and implemented and what the institutional framework for entrepreneurship may look like. These chapters explore how the three EU institutions reacted to the emerging economic crisis and acted to limit its negative consequences on the EU by forming new initiatives and policies to promote entrepreneurship and growth. They further identify internal debates and divisions on possible decisions and strategies to be taken and search for signs of political entrepreneurship by scrutinising official documents, action plans, debates and speeches.

Third, the theme of EU Embedded Policies on Entrepreneurship and Regional Growth, in Chapters 7 to 10, focuses on the role of political entrepreneurship within important EU policy areas. In its efforts to increase economic growth and employment, the EU has been interested in promoting entrepreneurship and growth through support from other policy areas. European politicians have often emphasised how the European economy needs to be supported by all policy areas and groups of society. EU policies often refer future economic growth to new industrial smart policies, policies on higher education, agriculture and migration etc., but also through entrepreneurial diversity in the importance of 
including women, immigrants and young adults in established economic and social networks for political and economic entrepreneurship.

Fourth, the theme of Case Studies on Local Political Entrepreneurship, in Chapters 11 and 12, addresses local/regional political entrepreneurship in times of Europeanisation, glocalisation (globalisation and localisation) and urbanisation and how local/regional actors in cities and municipalities may address ongoing economic structural transformations based on political entrepreneurship to see local growth, employment and social welfare. Both cities and municipalities are actors often addressed in the European debate as core entities for local and regional growth, employment and sustainable welfare. In a time of glocalisation, political entrepreneurship must not only be initiated from a top-down perspective, but more importantly be addressed by local initiatives to mitigate and adjust to major structural changes in Europe.

The fifth and final part, Concluding Remarks, Chapter 13, summarises the main findings or lessons learned on European governance and political entrepreneurship. This concluding part sheds light on how the political entrepreneur and political entrepreneurship are particularly important in times of economic crisis where normal work routines and everyday work do not necessarily solve European economic and societal challenges. In a time of profound socioeconomic challenges, it is particularly important to see political entrepreneurship that challenges traditional formal and informal institutions. The study on political entrepreneurship is thus to study what alternative approaches European politicians, bureaucrats, officials and institutions may take to provide better conditions for entrepreneurship and growth in Europe.

\section{REFERENCES}

Aberbach, J.D. and B.A. Rockman (1994). "Civil servants and policymakers: neutral or responsive competence?", Governance, 7(4): 461-9.

Aberbach, J.D., R.D. Putnam and B.A. Rockman (1981). Bureaucrats and Politicians in Western Democracies. Cambridge, MA: Harvard University Press.

Aldrich, H.E. (1990). "Using an ecological perspective to study organization founding rates", Entrepreneurship Theory and Practise, 19(4): 7-24.

Aldrich, H.E. and M.C. Fiol (1994). "Fools rush in? - The institutional context of industry creation", Academy of Management Review, 19(4): 645-70.

Amadeo, K. (2016). "11 Causes of the Economic Recession", The Balance. 28 December, accessed 21 March 2017 at https://www.thebalance.com/causes-ofeconomic-recession-3306010.

Avery, G. and F. Cameron (1999). The Enlargement of the European Union. Sheffield: Sheffield Academic Press. 
Bickerton, C., D. Hodson and U. Puetter (2015). "The new intergovernmentalism: European integration in the post-Maastricht era", Journal of Common Market Studies, 53(4): 703-22.

Borzaga, C., G. Galera and R. Nogales (eds) (2008). Social Enterprise: A New Model for Poverty Reduction and Employment Generation - An Examination of the Concept and Practice in Europe and the Commonwealth of Independent States. UNDP Regional Bureau for Europe and the Commonwealth of Independent States.

Börzel, T. (1999). "Towards convergence in Europe? Institutional adaption to Europeanization in Germany and Spain", Journal of Common Market Studies, 39(4): 573-96.

Börzel, T. (2002). "Pace-setting, foot-dragging, and fence-sitting: Member State responses to Europeanization", Journal of Common Market Studies, 40(2): 193-214.

Börzel, T. and D. Panke (2009). "Europeanization", in M. Cini and N. PérezSolórzano Borragán (eds), European Union Politics. Oxford and New York: Oxford University Press.

Börzel, T. and T. Risse (2000). When Europe Hits Home: Europeanization and Domestic Change. Florence: European University Institute, No. 2000/56.

Brickerhoff, P.C. (2000). Social Entrepreneurship - The Art of Mission-Based Venture Development. New York: John Wiley and Sons.

Casson, M.C. (1995). Entrepreneurship and Business Culture. Aldershot and Brookfield, VT: Edward Elgar.

Castells, M. (1996). The Rise of the Network Society: The Information Age: Economy, Society and Culture, Vol. 1. Oxford: Blackwells.

Com (2008). "'Think Small First' - A 'Small Business Act' for Europe”, 394 final. Brussels: European Commission.

Cowles, M.G., J.A. Caporaso and T. Risse (2001). Transforming Europe: Europeanization and Domestic Change. Ithaca, NY: Cornell University Press.

Dahl, R.A. (1974). Who Governs? Democracy and Power in an American City. New Haven, CT: Yale University Press.

Dullien, S., J. Detlef, J. Kotte, A. Márquez and J. Priewe (2010). "Introduction", in S. Dullien, J. Detlef, J. Kotte, A. Márquez and J. Priewe (eds), The Financial and Economic Crisis of 2008-2009 and Developing Countries. United Nations: New York and Geneva.

Dyson, K. and K. Goetz (2002). Conference Paper (unpublished) - Germany and Europe: Beyond Congruence. 11 March 2002 at Conference British Academy.

EUR-Lex, OMC (2017). Open Method of Coordination, accessed 17 October 2017 at http://eur-lex.europa.eu/summary/glossary/open_method_coordination. html.

European Commission (2009). Economic Crisis in Europe: Causes, Consequences and Responses - European Economy 7. Brussels: DG Economic and Financial Affairs.

European Commission (2010). Europe 2020 - A Strategy for Smart, Sustainable and Inclusive Growth. COM (2010) 2020 final. Brussels: European Commission. 
European Commission (April 2015). European Financial Stability and Integration - Commission Staff Working Document on European Financial Stability and Integration Review. SWD 98 final. Brussels: European Commission.

FCIC - The Financial Crisis Inquiry Commission (2011). The Financial Crisis Inquiry Report - Final Report of the National Commission on the Causes of the Financial and Economic Crisis in the United States. Washington DC: U.S. Government Printing Office.

Financial Times (2016). The 2008 to 2009 Global Financial Crisis Unfolds, accessed 11 May 2017 at http://lexicon.ft.com/Term?term=global-financialcrisis.

Finnemore, M. and K. Sikkink (1998). "International norm dynamics and political change", International Organizations, 52(4): 887-917.

Gawell, M., B. Johannisson and M. Lundqvist (2009). Samhällets entreprenörer - En forskarantologi om samhällsentreprenörskap (Social Entrepreneurs - A Research Anthology on Social Entrepreneurship). Stockholm: KK-stiftelsen.

Grant, A. (1998). "Entrepreneurship - the major academic discipline for the business economic curriculum for the 21 st century", in M.G. Scott, P. Rosa and H. Klandt (eds), Educating Entrepreneurs for Wealth Education. Burlington, VT: Ashgate.

Haas, E.B. (1958). The Uniting of Europe. Stanford, CA: Stanford University Press.

Held, D. (2000). "The changing contours of political community - rethinking democracy in the context of globalization", in B. Holden (ed.), Global Democracy: Key Debates. London and New York: Routledge.

Héritier, A., D. Kerwer, C. Knill, D. Lehmkuhl, M. Teutsch and A.C. Douillet (2001). Differential Europe: The European Union Impact on National Policymaking. Lanham, MD: Rowman \& Littlefield.

Hix, S. (1998). "The study of the European Union 11: the new governance agenda and its rivals", Journal of European Public Policy, 5(1): 38-65.

Hix, S. and K. Goetz (2000). "Introduction: European integration and national political systems", West European Politics, 23(4): 1-26.

Hofstede, G. (1991). Organisationer och kulturer - om interkulturell förståelse (Organizations and Cultures - Intercultural Understanding). Lund: Studentlitteratur.

Holcombe, R.G. (2002). "Political entrepreneurship and the democratic allocation of economic resources", The Review of Austrian Economics, 15(2/3): $143-59$.

Jones, P. (1978). "The appeal of the political entrepreneur", British Journal of Political Science, 8(4): 498-504.

Karlsson, C., D. Silander and C. Silander (2016). Political Entrepreneurship Regional Growth and Entrepreneurial Diversity in Sweden. Cheltenham: Edward Elgar.

Keohane, R.O. and J.S. Nye Jr. (1977). Power and Interdependence: World Politics in Transition. Boston, MA: Little, Brown.

Kingdon, J.W. (1984). Agendas, Alternatives and Public Policies. New York: HarperCollins.

Ladrech, R. (1994). "Europeanization of domestic politics and institutions: the case of France", Journal of Common Market Studies, 32(1): 69-88. 
Ladrech, R. (2010). Europeanization and National Politics. Basingstoke: Palgrave Macmillan.

Lisbon Treaty (2009). The Lisbon Treaty, accessed 17 October 2017 at http:// www.lisbon-treaty.org/wcm/the-lisbon-treaty/treaty-on-european-union-andcomments/title-1-common-provisions/9-article-5.html.

Marks, G. and L. Hooghe (2001). Multilevel Governance and European Integration. Lanham, MD: Rowman \& Littlefield.

McCaffrey, M. and J.T. Salerno (2011). "A theory of political entrepreneurship", Modern Economy, 2(4): 552-60.

Mintrom, M. and P. Norman (2009). "Policy entrepreneurship and policy change", The Policy Studies Journal, 37(4): 649-67.

Moravcsik, A. (1993). "Preferences and power in the European community: a liberal intergovernmentalist approach", Journal of Common Market Studies, 31(4): 473-524.

Moravcsik, A. (1998). The Choice of Europe - Social Purpose and State Power from Messina to Maastricht. London and New York: Routledge.

Morgan, G. (1986). Images of Organizations. Los Angeles, CA: Sage Publications.

Nier, E. and G. Forte (2016). Preventing the Next Financial Crisis. Washington, DC: International Monetary Fund.

North, D.C. (1990). Institutions, Institutional Change and Economic Performance. Cambridge: Cambridge University Press.

Olsen, J.P. (2002). "The many faces of Europeanization", Journal of Common Market Studies, 40(5): 921-52.

Putnam, R. (1993). Making Democracy Work - Civic Traditions in Modern Italy. Princeton, NJ: Princeton University Press.

Quaglia, L., M. Miyakoshi and M. Cini (2007). "Europeanization”, in M. Cini (ed.), European Union Politics, 2nd edition. Oxford: Oxford University Press.

Radaelli, C. (2000). "Whither Europeanization? Concept stretching and substantive change", European Integration, online papers, 4/8.

RealtyTrac (2008). U.S. Foreclosure Activity Increase 75 percent in 2007. 30 January, accessed 25 April 2017 at http://www.realtytrac.com/content/pressreleases/us-foreclosure-activity-increases-75-percent-in-2007-3604.

Rhodes, R.A.W. (1996). "The new governance: governing without government", Political Studies, 44(3): 652-67.

Risse, T., M.G. Cowles and J. Caporaso (2001). "Europeanization and domestic change: introduction", in T. Risse, M.G. Cowles and J. Caporaso (eds), Transforming Europe: Europeanization and Domestic Change. Ithaca, NY: Cornell University Press.

Salerno, J.T. (2008). "The entrepreneur: real and imagined", Quarterly Journal of Austrian Economics, 11(3): 188-207.

Scheingate, A.D. (2003). "Political entrepreneurship, institutional change and American political development", Studies in American Political Development, 17(2): 185-203.

Schneider, M. and P. Teske (1992). "Toward a theory of the political entrepreneur: evidence from local government", American Political Science Review, 86(3): 737-47. 
Schumpeter, J.A. (1943). Capitalism, Socialism and Democracy. London: Unwin.

Silander, D. (2016). "The political entrepreneur", in C. Karlsson, D. Silander and C. Silander (eds), Political Entrepreneurship - Regional Growth and Entrepreneurial Diversity in Sweden. Cheltenham and Northampton: Edward Elgar.

Silander, D. and C. Silander (2015). Politiskt Entreprenörskap - den offentliga sektorns sätt att skapa bättre förutsättningar för entreprenörskap lokalt, regional och nationellt (Political Entrepreneurship) - (Public Sector Ways to Create Better Conditions for Entrepreneurship Locally, Regionally and Nationally), Stockholm: Santérus förlag.

Simmons, R.T., R.M. Yonk and D.W. Thomas (2011). "Bootleggers, baptists, and political entrepreneurs - key players in the rational game and morality play of regulatory politics", The Independent Review, 15(3): 367-81.

Suter, C. and M. Herkenrath (2012). World Society in the Global Economic Crisis. Zurich/Berlin: LIT Verlag Dr W Hopf.

The Economist (2007). CSI: Credit Crunch. 17 October, accessed 21 March 2017 at http://www.economist.com/node/9972489.

The Economist (2017). Economist - A Helping Hand to Homeowners, accessed 25 April 2017 at http://www.economist.com/node/12470547.

The State of the Nation's Housing (2008). Joint Center for Housing Studies of Harvard University. Harvard: 2008 President and Fellows of Harvard College.

Turcu, C., N. Karadimitriou and S. Chaytor (2015). The Impact of the Global Financial and Economic Crisis on European Cities. London: University College London, accessed 3 April 2017 at https://www.ucl.ac.uk/public-policy/ for-policy-professionals/research-insights/Crisis_briefing.pdf.

Wallace, H. (2000). "Europeanisation and globalisation: complementary or contradictory trends?", New Political Economy, 5(3): 369-82.

Wallace, H., M.A. Pollack and A.R. Young (2010). "An overview" in H. Wallace, M.A. Pollack and A.R. Young (eds), Policy-Making the European Union. Oxford: Oxford University Press.

Warleigh-Lack, A. and R. Drachenberg (2013). "Policymaking in the European Union", in M. Cini and N. Pérez-Solórzano Borragán (eds), European Union Politics, 4th edition. Oxford: Oxford University Press, pp. 199-212.

Westlund, H. (2010). Multidimensional Entrepreneurship: Theoretical Considerations and Swedish Empirics: Conference Paper, 19-23 August 2010. Jönköping: European Regional Science Association, Sweden. 